\title{
Validation of Virus NAT for HIV, HCV, HBV and HAV Using Post-Mortal Blood Samples
}

\author{
Knut Gubbe $^{\mathrm{a}}$ Yvonne Scharnagl $^{\mathrm{b}} \quad$ Steffi Grosch $^{\mathrm{b}}$ Torsten Tonn ${ }^{\mathrm{b}} \quad$ Michael Schmidt $^{\mathrm{b}}$ \\ Kai M. Hourfar ${ }^{b}$ Andreas Karl ${ }^{b}$ Erhard Seifried $^{b}$ Ina Wilkemeyer ${ }^{c} \quad$ Ulrich Kalus $^{c}$ \\ ${ }^{a}$ German Red Cross Blood Donation Service East, Institute for Transfusion Medicine and Immunohematology Plauen, \\ ${ }^{b}$ German Red Cross Blood Donation Service Baden-Württemberg-Hesse, Institute for Transfusion Medicine and Immunohematology, \\ Frankfurt/M. \\ c Tissue Bank, Institute for Transfusion Medicine; Charité - University Medicine Berlin, Germany
}

\section{Keywords}

NAT · Post-mortem blood · Tissue donation · Validation . HCV $\cdot$ HIV $\cdot$ HBV $\cdot$ HAV

\section{Summary}

Objective: Commercial available NAT systems are usually not validated for screening of post-mortem blood samples. NAT testing might be challenging due to inhibitory substances in the cadaveric blood sample that cause false-negative test results. Validation studies have to be performed to show the performance characteristics of the NAT assays for testing cadaveric blood. Methods: A set of 32 post-mortem serum and plasma samples from cornea donors and 40 control samples from blood donors, serologically and NAT negative for all investigated parameters, were spiked with defined concentrations of WHO reference material and tested for HIV-1, HCV, HBV, and HAV by NAT using DRK Baden-Württemberg-Hesse CE PCR kits. Analytical sensitivity, analytical specificity and reproducibility/precision were validated and compared with each other in both groups of samples. Results: The analytical sensitivity was $100 \%$ for control and post-mortem specimens when spiked with virus standards at concentrations of $3 \times$ level of detection (LOD). Invalid results did not occur. The analytical specificity rate for all assays was $100 \%$. Intra-assay variation was analyzed as a function of sample material and sampling time post mortem. Values of \% coefficient of variation (\%CV) were comparable for serum and plasma but slightly higher for post-mortem samples especially for those samples collected more than $24 \mathrm{~h}$ post mortem. Conclusion: Based on the presented validation, postmortem donor samples can be tested with the automated DRK Baden-Würtemberg-Hesse NAT system.

\section{Schlüsselwörter}

NAT · Post-mortem-Blut · Gewebespende · Validierung · $\mathrm{HCV} \cdot \mathrm{HIV} \cdot \mathrm{HBV} \cdot \mathrm{HAV}$

\section{Zusammenfassung}

Hintergrund: Kommerzielle NAT Assays sind üblicherweise nicht für das Screening von Post-mortem-Blut validiert. Die Durchführung der NAT-Testung ist aufgrund inhibitorischer Substanzen im Blut Verstorbener schwierig und kann zu falsch-negativen Testergebnissen führen. Um die Leistungsmerkmale der NAT-Assays für die Testung von Post-mortem-Blut zu bestimmen, müssen Validierungsuntersuchungen durchgeführt werden. Methoden: Plasma- und Serumproben von insgesamt 32 Hornhautspendern (Cornea) und 40 Kontrollproben von Blutspendern wurden serologisch und mittels NAT negativ auf HIV-1, HCV, HBV und HAV getestet. Aliquots dieser Proben wurden mit definierten Konzentrationen von WHO-NAT-Standardpräparationen gespickt und die Leistungsmerkmale der Assays wie Sensitivität, Spezifität und Reproduzierbarkeit bzw. Präzision validiert. Ergebnisse: Die analytische Sensitivität betrug $100 \%$ sowohl für die Kontrollproben als auch für die Post-mortem-Proben. Alle Proben, die mit einer Viruskonzentration des dreifachen der Nachweisgrenze gespickt worden waren, wurden NAT-positiv detektiert. Die analytische Spezifität der NAT-Assays lag bei jeweils $100 \%$. Es kam zu keinen invaliden Testergebnissen. Die Intra-Assay-Präzision war bei Testung der Kontrollproben am höchsten. Ein höherer \% Variationskoeffizient (\%CV) wurde für Post-mortemProben im Vergleich zu den Kontrollproben ermittelt und zeigte sich insbesondere bei Proben, die später als $24 \mathrm{~h}$ post mortem entnommen wurden. Schlussfolgerung: Die validierten DRK-Baden-Würtemberg-Hessen-PCRAssays sind für das automatisierte Screening von Postmortem-Spenderproben geeignet.

\section{KARGER \\ Fax +497614520714 \\ Information@Karger.de}

www.karger.com
(C) 2012 S. Karger GmbH, Freibur

1660-3796/12/0396-0381\$38.00/0

Accessible online at:

www.karger.com/tm
Dr. Knut Gubbe

DRK Blutspendedienst Ost gemeinnützige $\mathrm{GmbH}$

ITM Plauen

Röntgenstraße 2a, 08529 Plauen, Germany

k.gubbe@blutspende.de 


\section{Introduction}

A high standard of viral safety of tissues for transplantation is guaranteed when using well validated test systems for viruses like HIV, HCV, HBV, and HAV. Serological screening of tissue donors is mandatory by EU and German law (EU directives 2006/17/EC and TPGGewV). While NAT have been established for blood donor screening since 1996 in Germany [1,2], the detection of viral genomes in blood samples from tissue donors (post and pre mortem) is not described, neither in the requirements of the EU nor in the German Transplant Act.

Currently most tissue donors are only tested using immunoassays to detect antigens or antibodies that appear much later in the infection cycle than viral genome [3].

NAT systems are able to shorten the diagnostic window period to a minimum and to increase blood safety to the highest standard [4-7]. The presence of inhibitors due to hemolysis of the samples may lead to false-negative results or a reduced analytical sensitivity of the NAT system. An efficient extraction procedure is therefore essential for the performance of the NAT.

This article describes the validation of the DRK Baden-Würtemberg-Hesse PCR test system in combination with the extraction on the Zelos x100 platform for the detection of HIV-1, HBV, $\mathrm{HCV}$, and HAV in blood samples of deceased cornea donors.

To assess the performance, we determined the analytical sensitivity, the analytical specificity, and the reproducibility/precision by testing cadaveric samples compared to control (living) blood donor specimens.

\section{Material and Methods}

\section{Study Design}

In order to validate the performance characteristics of a NAT for cadaveric indication, the optimal choice is to use matched pairs of pre- and post-mortem specimens for the experiments as recommended by Paul Ehrlich Institute.

Due to the fact only 8 pre-mortem/post-mortem matched pairs of specimens were available, we have used plasma and serum specimens from living donors (blood donors) as control too. Aliquots of control and cadaveric specimens were used in spiking experiments in order to evaluate assay features like sensitivity, specificity, and reproducibility.

\section{Samples}

Sets of 20 control serum and 20 plasma aliquots were taken from blood donor samples after routine screening for viral markers. Whole blood was centrifuged with $3,500 \times g$ for $15 \mathrm{~min}$, serum or plasma was removed and then stored at $2-8{ }^{\circ} \mathrm{C}$ for up to $24 \mathrm{~h}$ before testing.

A set of 16 post-mortem serum and 16 plasma blood samples were obtained from donors between 11 and $54 \mathrm{~h}$ (mean $31.5 \mathrm{~h}$ ) after death and were provided by the University Tissue Bank of the Charité University Berlin. Eight matched pairs of pre-mortem/post-mortem samples were included in the study. Samples were treated as described elsewhere [8].

All samples were serologically tested negative for anti-HIV-1/2, antiHCV and HBsAg using Enzygnost ${ }^{\circledR}$ Anti-HIV-1/2 Plus (Siemens, Munich, Germany), HCV-version 3.0 ELISA with Enhanced Save (Ortho Clinical Diagnostics, Neckargemünd, Germany), Enzygnost HBsAg version 6.0 and Enzygnost anti-HBc monoclonal assays on the Siemens BEP III Automatic System (post-mortem specimens), or using ABBOTT PRISM HIVAg/Ab Combo Assay, ABBOTT PRISM HCV Assay Kit, ABBOTT PRISM HBsAg Assay Kit and ABBOTT PRISM HBcore Assay Kit on the AB-
Table 1. List of WHO NAT standards

\begin{tabular}{ll}
\hline Virus & $\begin{array}{l}\text { WHO international standard / } \\
\text { NIBSC -code }\end{array}$ \\
\hline HCV & HCV 06/102 \\
HBV & HBV $10 / 264$ \\
HAV & HAV 00/560 \\
HIV & HIV $97 / 650$ \\
\hline
\end{tabular}

Table 2. List of NAT test kits

\begin{tabular}{ll}
\hline Test kit & $95 \% \mathrm{LOD}, \mathrm{IU} / \mathrm{ml}$ \\
\hline DRK HIV-1 PCR kit & 8.9 \\
DRK HCV PCR kit & 6.8 \\
DRK HBV PCR kit & 0.6 \\
DRK HAV PCR kit & 0.65 \\
\hline
\end{tabular}

BOTT Prism System (control specimens) (all Abbott GmbH \& Co. KG, Wiesbaden, Germany).

Non-spiked aliquots of control and post-mortem specimens were first tested by NAT to verify their non-reactivity for HIV-1, HCV, HBV, and HAV.

\section{Spiking with WHO International Standards}

A second aliquot of each specimen was spiked with a dilution of a WHO standard preparation of the respective virus at $3 \times$ level of detection (LOD) as recommended by the Paul Ehrlich Institute. Dilutions of standard material were done using NAT and serologically negative human plasma.

A list of WHO NAT standards that have been used for spiking experiments is shown in table 1.

\section{Extraction of Nucleic Acids}

Nucleic acid extraction was performed on a Zelos x100 platform using the chemagic viral DNA and RNA kit special (PerkingElmer, chemagen Technologie $\mathrm{GmbH}$, Baesweiler, Germany). Extraction procedure is described elsewhere [9]. This method in combination with DRK PCR assays is applied routinely for blood donor screening for HIV-1, HCV, HBV, HAV, and parvovirus-B19 in minipools of 96 plasma samples and was used for preparation of viral nucleic acids from single cadaveric samples in this study too.

Extraction was performed with $100 \mu \mathrm{l}$ sample material that was mixed with $4.7 \mathrm{ml}$ phosphate buffered saline (PBS) to simulate a sample volume similar to a size of a minipool. Nucleic acids were eluted in $100 \mu \mathrm{l}$ of elution buffer.

\section{NAT Tests for the Detection of HIV-1, HCV, HBV and HAV}

Serum and plasma samples were analyzed using DRK PCR kits (German Red Cross Blood Service Baden-Württemberg-Hesse, Frankfurt/M., Germany) which are CE marked real-time PCR assays for blood donor screening in minipools up to a maximum pool size of 96 samples per pool. Test kits are listed in table 2 .

\section{Statistics}

Standard deviation, coefficient of variation (CV) and Wilcoxon signed-rank test were calculated using Excel software (Microsoft Corp., Redmont, WA, USA)

\section{Results}

\section{Analytical Sensitivity}

In order to validate the analytical sensitivity of the assays, control and post-mortem samples were spiked with WHO standard preparations at $3 \times$ LOD of the respective virus. The positivity rate of all DRK-PCR assays was $100 \%$ for both control and post-mortem samples (table 3 ). 


\section{Analytical Specificity}

Non-spiked aliquots of samples from blood donors (control) and post-mortem donors tested negative by all NAT assays. Specificity of NAT assays was $100 \%$ for both control and postmortem specimens for all parameters (table 4).

\section{Reproducibility/Precision}

We have analyzed mean threshold cycle, SD and \%CV of control samples versus post-mortem samples. The \% CV of postmortem samples did not exceed the value of 4.94 for the virus signal and 3.30 for the IC signal and is slightly higher than the $\% \mathrm{CV}$ of the control samples (table 5). These findings could be confirmed in a comparison with 8 pre-mortem/post mortem sample pairs (table 6).

Additionally we compared serum and plasma post-mortem samples as a function of sample material (table 7) and of sampling time post mortem (table 8).

Variation coefficients of serum and plasma control samples and post-mortem samples were comparable, whereas \% CV of samples collected more than $24 \mathrm{~h}$ post mortem were slightly higher than those of samples which were collected up to $24 \mathrm{~h}$ after death.

All NAT tests included internal controls that monitored each PCR reaction. No reaction was invalid. Although 9 of 32 postmortem samples were highly hemolyzed (dark red in appearance), they could be verified to be correctly negative (nonspiked) or positive when spiked with defined concentrations of virus reference material.

Statistically significant differences as a function of sample material and sampling time were not found by the Wilcoxon test (data not shown).

\section{Discussion}

Studies showed the additional benefit of NAT testing for the safety of tissue and organ transplants [10-13].
Table 3. Sensitivity data of the DRK PCR assays in cadaveric and control donor specimens

\begin{tabular}{llll}
\hline Donor & $\begin{array}{l}\text { Number of } \\
\text { samples }\end{array}$ & $\begin{array}{l}\text { Validity } \\
\text { rate, \% }\end{array}$ & $\begin{array}{l}\text { Reactivity } \\
\text { rate, \% }\end{array}$ \\
\hline HIV & & & \\
Control & 40 & 100 & 100 \\
Cadaveric & 32 & 100 & 100 \\
$H C V$ & & & \\
Control & 40 & 100 & 100 \\
Cadaveric & 32 & 100 & 100 \\
$H B V$ & & & \\
Control & 40 & 100 & 100 \\
Cadaveric & 32 & 100 & 100 \\
$H A V$ & & & \\
Control & 40 & 100 & 100 \\
Cadaveric & 32 & 100 & 100 \\
\hline
\end{tabular}

Table 4. Specificity data of the DRK PCR assays in cadaveric and control donor specimens

\begin{tabular}{llll}
\hline Donor & $\begin{array}{l}\text { Number of } \\
\text { samples }\end{array}$ & $\begin{array}{l}\text { Validity } \\
\text { rate, \% }\end{array}$ & $\begin{array}{l}\text { Specificity } \\
\text { rate, \% }\end{array}$ \\
\hline HIV & & & \\
Control & 40 & 100 & 100 \\
Cadaveric & 32 & 100 & 100 \\
$H C V$ & & & \\
Control & 40 & 100 & 100 \\
Cadaveric & 32 & 100 & 100 \\
$H B V$ & & & \\
Control & 40 & 100 & 100 \\
Cadaveric & 32 & 100 & 100 \\
$H A V$ & & & \\
Control & 40 & 100 & 100 \\
Cadaveric & 32 & 100 & 100 \\
\hline
\end{tabular}

Table 5. Reproducibility/precision (intra-assay) data of the DRK PCR assays in cadaveric and control donor specimens

\begin{tabular}{|c|c|c|c|c|c|c|}
\hline \multirow[t]{2}{*}{ Analyte } & \multicolumn{3}{|c|}{ Control donor specimen $(n=40)$} & \multicolumn{3}{|c|}{ Cadaveric donor specimen $(\mathrm{n}=32)$} \\
\hline & mean $\mathrm{Ct}$ & SD & $\% \mathrm{CV}$ & mean $\mathrm{Ct}$ & SD & $\% \mathrm{CV}$ \\
\hline \multicolumn{7}{|l|}{ HIV } \\
\hline IC & 24.32 & 0.30 & 1.20 & 24.80 & 0.43 & 1.74 \\
\hline Virus & 24.80 & 0.50 & 1.89 & 24.54 & 0.98 & 3.98 \\
\hline \multicolumn{7}{|l|}{$\mathrm{HCV}$} \\
\hline IC & 24.62 & 0.20 & 0.80 & 24.53 & 0.24 & 0.98 \\
\hline Virus & 26.60 & 0.47 & 1.76 & 26.34 & 0.86 & 3.25 \\
\hline \multicolumn{7}{|l|}{$H B V$} \\
\hline IC & 23.30 & 0.41 & 1.70 & 23.96 & 0.79 & 3.30 \\
\hline Virus & 27.60 & 0.25 & 1.10 & 27.51 & 0.84 & 3.07 \\
\hline \multicolumn{7}{|l|}{$H A V$} \\
\hline IC & 21.61 & 0.83 & 3.18 & 22.89 & 0.57 & 2.49 \\
\hline Virus & 23.82 & 0.19 & 0.80 & 23.65 & 0.42 & 1.79 \\
\hline
\end{tabular}


Table 6. Reproducibility/precision (intra-assay) data of the DRK PCR assays from matched pre mortem / post mortem sample pairs

\begin{tabular}{|c|c|c|c|c|c|c|}
\hline \multirow[t]{2}{*}{ Analyte } & \multicolumn{3}{|c|}{ Pre-mortem specimen $(\mathrm{n}=8)$} & \multicolumn{3}{|c|}{ Post-mortem specimen $(\mathrm{n}=8)$} \\
\hline & mean $\mathrm{Ct}$ & SD & $\% \mathrm{CV}$ & mean $\mathrm{Ct}$ & SD & $\% \mathrm{CV}$ \\
\hline \multicolumn{7}{|l|}{ HIV } \\
\hline IC & 24.82 & 0.31 & 1.24 & 24.72 & 0.23 & 0.92 \\
\hline Wild type & 25.49 & 0.71 & 2.80 & 25.53 & 1.26 & 4.94 \\
\hline \multicolumn{7}{|l|}{$H C V$} \\
\hline IC & 24.52 & 0.19 & 0.75 & 24.7 & 0.19 & 0.75 \\
\hline Wild type & 25.25 & 0.40 & 1.55 & 25.43 & 0.29 & 1.14 \\
\hline \multicolumn{7}{|l|}{$H B V$} \\
\hline IC & 23.97 & 0.28 & 1.16 & 24.19 & 0.25 & 1.07 \\
\hline Wild type & 28.15 & 0.49 & 1.73 & 28.04 & 0.49 & 1.74 \\
\hline \multicolumn{7}{|l|}{$H A V$} \\
\hline IC & 22.18 & 0.22 & 1.00 & 22.47 & 0.16 & 0.73 \\
\hline Wild type & 23.74 & 0.53 & 2.24 & 23.71 & 0.53 & 2.22 \\
\hline
\end{tabular}

Table 7. Reproducibility/precision (intra-assay) data of the DRK PCR assays in cadaveric serum and plasma specimens

\begin{tabular}{|c|c|c|c|c|c|c|}
\hline \multirow[t]{2}{*}{ Analyte } & \multicolumn{3}{|c|}{ Post-mortem serum $(\mathrm{n}=16)$} & \multicolumn{3}{|c|}{ Post-mortem plasma $(\mathrm{n}=16)$} \\
\hline & mean $\mathrm{Ct}$ & SD & $\% \mathrm{CV}$ & mean $\mathrm{Ct}$ & SD & $\% \mathrm{CV}$ \\
\hline \multicolumn{7}{|l|}{ HIV } \\
\hline IC & 25.00 & 0.47 & 1.89 & 24.64 & 0.32 & 1.30 \\
\hline Virus & 24.46 & 0.75 & 3.07 & 24.63 & 1.18 & 4.80 \\
\hline \multicolumn{7}{|l|}{$\mathrm{HCV}$} \\
\hline IC & 24.51 & 0.25 & 1.02 & 24.67 & 0.57 & 2.29 \\
\hline Virus & 26.34 & 0.70 & 2.67 & 26.35 & 1.01 & 3.83 \\
\hline \multicolumn{7}{|l|}{$H B V$} \\
\hline IC & 24.15 & 1.07 & 4.42 & 23.74 & 0.30 & 1.27 \\
\hline Virus & 27.62 & 1.06 & 3.86 & 27.40 & 0.56 & 2.03 \\
\hline \multicolumn{7}{|l|}{$H A V$} \\
\hline IC & 23.00 & 0.57 & 2.47 & 22.90 & 0.71 & 3.10 \\
\hline Virus & 23.69 & 0.35 & 1.47 & 23.62 & 0.50 & 2.10 \\
\hline
\end{tabular}

Table 8. Reproducibility/precision (intra-assay) data of the DRK PCR assays in cadaveric specimens as a function of sampling time post mortem

\begin{tabular}{|c|c|c|c|c|c|c|}
\hline \multirow[t]{2}{*}{ Analyte } & \multicolumn{3}{|c|}{ Up to $24 \mathrm{~h}$ post mortem $(\mathrm{n}=8)$} & \multicolumn{3}{|c|}{ Up to $57 \mathrm{~h}$ post mortem $(\mathrm{n}=24)$} \\
\hline & mean $\mathrm{Ct}$ & SD & $\% \mathrm{CV}$ & mean $\mathrm{Ct}$ & SD & $\% \mathrm{CV}$ \\
\hline \multicolumn{7}{|l|}{$H I V$} \\
\hline IC & 24.66 & 0.19 & 0.77 & 24.84 & 0.47 & 1.90 \\
\hline Virus & 24.69 & 0.60 & 2.43 & 24.53 & 1.03 & 4.21 \\
\hline \multicolumn{7}{|l|}{$\mathrm{HCV}$} \\
\hline IC & 24.55 & 0.19 & 0.76 & 24.54 & 0.28 & 1.16 \\
\hline Virus & 25.58 & 0.49 & 1.92 & 26.47 & 0.86 & 3.23 \\
\hline \multicolumn{7}{|l|}{$H B V$} \\
\hline IC & 23.81 & 0.43 & 1.79 & 24.18 & 1.25 & 5.16 \\
\hline Virus & 27.83 & 0.81 & 2.91 & 27.48 & 0.86 & 3.23 \\
\hline \multicolumn{7}{|l|}{$H A V$} \\
\hline IC & 22.41 & 0.42 & 1.88 & 23.07 & 0.54 & 2.36 \\
\hline Virus & 23.77 & 0.25 & 1.05 & 23.63 & 0.44 & 1.88 \\
\hline
\end{tabular}

By contrast, up to date the detection of viral genomes in blood samples from tissue donors (post and pre mortem) is not explicitly described, neither in the requirements of the EU nor in the German Transplant Act, and NAT testing is only voluntary.

In this study we validated the DRK Baden-WürttembergHesse PCR assays in combination with the extraction on the
Zelos x100 for the detection of HIV-1, HCV, HBV, and HAV in cadaveric tissue donor samples.

As only a small number of paired pre-mortem/post-mortem samples was available, we decided to include control samples from blood donors that were tested negative by routine antigen/ antibody and NAT screening. 
Positivity rates of spiked sample aliquots (serum versus plasma, control versus post mortem, pre-mortem/post-mortem pairs) were highly consistent, indicating $100 \%$ sensitivity.

The rate of unspecific reactive results was equivalent for all examined samples at zero. The highly congruent specificity of $100 \%$ shows the advantages of NAT compared to serologic assays where false reactivity can be a serious problem [8].

We could find only a slight influence of sampling time post mortem on the precision of NAT assays. Samples with a sampling time $>24 \mathrm{~h}$ had an elevated $\mathrm{CV}$ in comparison to samples with a post-mortem sampling time $<24 \mathrm{~h}$.

NAT testing of blood donors is routinely performed with plasma. For cadaveric indications NAT needs to be validated with both sample qualities. The DRK PCR assays are equally qualified for serum and plasma post-mortem samples.

The extraction method used is routinely utilized for the screening of high-volume minipool blood donor samples of up to 96 samples per minipool. Therefore, it has the capacity to reliably remove large amounts of PCR inhibitors such as hemoglobin. This could be demonstrated by the data of 9 highly hemolyzed post-mortem samples.
As a prolonged time slot for sampling would improve the availability of tissue donations [14], this method could be well suited for the testing of post-mortem samples collected later than $24 \mathrm{~h}$ from death when the amount of disturbing substances increases.

On the other hand, it is known that degradation of viral genomes is dependent on sampling time from death $[15,16]$. In order to verify the usability of NAT for screening of samples collected later than $24 \mathrm{~h}$ post mortem, further data on stability of HIV-1, HCV, HBV, and HAV in cadaveric samples need to be assessed. Such data are presented in another paper of this special issue [17].

In view of the validation data described in this study, we conclude that the DRK PCR assays fulfill all requirements of the Paul Ehrlich Institute and guarantee a reliable and highly sensitive detection of HIV-1, HCV, HBV, and HAV in cadaveric serum and plasma samples.

\section{Disclosure Statement}

The authors declared no conflict of interest.

\section{References}

1 Hourfar MK, Jork C, Schottstedt V, Weber-Schehl M, Brixner V, Busch MP, Geusendam G, Gubbe K, Mahnhardt C, Mayr-Wohlfart U, Pichl L, Roth WK, Schmidt M, Seifried E, Wright DJ: Experience of german red cross blood donor services with nucleic acid testing: Results of screening more than 30 million blood donations for human immunodeficiency virus- 1 , hepatitis C virus, and hepatitis B virus. Transfusion 2008;48:1558-1566.

$\checkmark 2$ Roth WK, Busch MP, Schuller A, Ismay S, Cheng A, Seed CR, Jungbauer C, Minsk PM, SondagThull D, Wendel S, Levi JE, Fearon M, Delage G, Xie Y, Jukic I, Turek P, Ullum H, Tefanova V, Tilk M, Reimal R, Castren J, Naukkarinen M, Assal A, Jork C, Hourfar MK, Michel P, Offergeld R, Pich L, Schmidt M, Schottstedt V, Seifried E, Wagner F, Weber-Schehl M, Politis C, Lin CK, Tsoi WC, O'Riordan J, Gottreich A, Shinar E, Yahalom V, Velati C, Satake M, Sanad N, Sisene I, Bon AH, Koppelmann M, Flanagan P, Flesland O, Brojer E, Letowska M, Nascimento F, Zhiburt E, Chua SS Teo D, Stezinar SL, Vermeulen M, Reddy R, Park Q, Castro E, Eiras A, Gonzales Fraile I, Torres P, Ekermo B, Niederhauser C, Chen H, Oota S, Brant LJ, Eglin R, Jarvis L, Mohabir L, Brodsky J, Foster G, Jennings C, Notari E, Stramer S, Kessler D, Hillyer C, Kamel H, Katz L, Taylor C, Panzer S, Reesink HW: International survey on NAT testing of blood donations: expanding implementation and yield from 1999 to 2009. Vox Sang 2012;102:82-90.

$\checkmark 3$ Dodd R, Kurt Roth W, Ashford P, Dax EM, Vyas G: Transfusion medicine and safety. Biologicals 2009;37:62-70.

4 Mueller MM, Hourfar MK, Huber E, Sireis W, Weichert W, Seifried E, Tonn T, Schmidt M: Oxygen measurements in platelet fluids - a new noninvasive method to detect bacterial contaminations in platelets. Transfus Med 2012;22:211-216.
5 Schmidt M, Pichl L, Jork C, Hourfar MK, Schottstedt V, Wagner FF, Seifried E, Muller TH, Bux J, Saldanha J: Blood donor screening with cobas s 201/cobas TaqScreen MPX under routine conditions at German Red Cross institutes. Vox Sang 2010;98:37-46.

6 Koppelman MH, Cuijpers HT, Wessberg S, Valkeajarvi A, Pichl L, Schottstedt V, Saldanha J: Multicenter evaluation of a commercial multiplex polymerase chain reaction test for screening plasma donations for parvovirus B19 DNA and hepatitis a virus RNA. Transfusion 2012;52:1498-1508.

7 Vermeulen M, Lelie N, Sykes W, Crookes R, Swanevelder J, Gaggia L, Le Roux M, Kuun E, Gulube S, Reddy R: Impact of individual-donation nucleic acid testing on risk of human immunodeficiency virus, hepatitis B virus, and hepatitis $\mathrm{C}$ virus transmission by blood transfusion in South Africa. Transfusion 2009 ;49:1115-1125.

-8 Kalus U, Wilkemeyer I, Caspari G, Schroeter J, Pruss A: Validation of the serological testing for anti-HIV-1/2, anti-HCV, HBsAg, and anti-HBC from post-mortem blood on the Siemens-BEP-III automatic system. Transfus Med Hemother 2011; 38:365-372.

9 Hourfar MK, Schmidt M, Seifried E, Roth WK: Evaluation of an automated high-volume extraction method for viral nucleic acids in comparison to a manual procedure with preceding enrichment. Vox Sang 2005;89:71-76.

10 Miedouge M, Chatelut M, Mansuy JM, Rostaing L, Malecaze F, Sandres-Saune K, Boudet F, Puel J, Abbal M, Izopet J: Screening of blood from potential organ and cornea donors for viruses. J Med Virol 2002;66:571-575.

11 Tugwell BD, Patel PR, Williams IT, Hedberg K, Chai F, Nainan OV, Thomas AR, Woll JE, Bell BP, Cieslak PR: Transmission of hepatitis $C$ virus to several organ and tissue recipients from an antibodynegative donor. Ann Intern Med 2005;143:648-654.
12 Ison MG, Llata E, Conover CS, Friedewald JJ, Gerber SI, Grigoryan A, Heneine W, Millis JM, Simon DM, Teo CG, Kuehnert MJ: Transmission of human immunodeficiency virus and hepatitis $\mathrm{C}$ virus from an organ donor to four transplant recipients. Am J Transplant 2011;11:1218-1225.

13 Pruss A, Caspari G, Kruger DH, Blumel J, Nubling CM, Gurtler L, Gerlich WH: Tissue donation and virus safety: more nucleic acid amplification testing is needed. Transpl Infect Dis 2010;12:375-386.

14 Edler C, Wulff B, Schroder AS, Wilkemeyer I, Polywka S, Meyer T, Kalus U, Pruss A: A prospective time-course study on serological testing for human immunodeficiency virus, hepatitis B virus and hepatitis $\mathrm{C}$ virus with blood samples taken up to $48 \mathrm{~h}$ after death. J Med Microbiol 2011;60:920-926.

15 Busch MP, Lee LL, Satten GA, Henrard DR, Farzadegan H, Nelson KE, Read S, Dodd RY, Petersen LR: Time course of detection of viral and serologic markers preceding human immunodeficiency virus type 1 seroconversion: implications for screening of blood and tissue donors. Transfusion 1995;35:91-7.

16 Eriksen MB, Jakobsen MA, Kringsholm B, Banner J, Thomsen JL, Georgsen J, Pedersen C, Christensen PB: Postmortem detection of hepatitis B, C, and human immunodeficiency virus genomes in blood samples from drug-related deaths in Denmark. J Forensic Sci 2009;54:1085-1088.

17 Meyer T, Polywka S, Wulff B, Edler C, Schröder AS, Wilkemeyer I, Kalus U, Pruss A: Virus NAT for HIV, HBV, and HCV in post-mortal blood specimens over $48 \mathrm{~h}$ after death of infected patients - first results. Transfus Med Hemother 2012; 39(6):376-380. 